\title{
PENTINGNYA PROFESI KEGURUAN BAGI INDONESIA
}

\author{
Yeni Lestari \\ Email: 2010111220013@mhs.ulm.ac.id \\ Program Studi Pendidikan Sejarah Fakultas Keguruan dan Ilmu Pendidikan \\ Universitas Lambung Mangkurat \\ Banjarmasin
}

\begin{abstract}
Abstrak
Profesi guru merupakan profesi yang sangat penting dan berkontribusi langsung terhadap kemajuan suatu bangsa. Guru merupakan posisi yang strategis bagi pemberdayaan dan pembelajaran suatu bangsa yang tidak mungkin dan digantikan oleh unsur manapun dan kehidupan sebuah bangsa sejak dulu. Profesi adalah pekerjaan atau jabatan yang menuntut keahlian, yang didapat melalui pendidikan dan latihan tertentu, menurut peryaratan kusus memiliki tanggung jawab dan kode etika tertentu. Dan profesi keguruan adalah jabatan yang memerlukan keahlian kusus sebagai guru dan tidak dapat dilakukan oleh sembarang orang diluar bidang pendidikan. Guru merupakan profesi tertua didunia dan seumur dengan keberadaan manusia. Guru dapat digolongkan sebagi sebuah profesi mengapa demikian katrena sebuah profesi merupakan suatu pekerjaan atau jabatan yang menuntut keahlian yang didapatkan melalui pendidikan. Profesi guru juga dilengkapi oleh undang-undang yang menjamin hak dan kewajiban guru indonesia. Seperti layaknya profesi lain, untuk menjadi guru profesional diperlukan beberapa kriteria berupa landasan keprofesionalan profesi guru dan kompetensi guru sebagaimana tentunya dalam Undang-Undang guru dan dosen.
\end{abstract}

\section{PENDAHULUAN}

Profesi secara etimologi berasal dari kata profession (inggris), yang berasal dari bahasa latin profesus yang berarti "mampu atau ahli dalam suatu bentuk pekerjaan". Profesi dapat diartikan sebagai suatu pekerjaan atau jabatan yang menuntut keahlian, yang didapat melalui pendidikan dan latihan tertentu, menurut persyaratan khusus memiliki tanggung jawab dan kode etika tertentu. Profesi juga diartikan sebagai suatu jabatan atau pekerjaan tertentu yang masyarakat pengetahuan dan keterampilan khusus yang diperoleh dari pendidikan akademis yang intensif. Jadi profesi merupakan suatu pekerjaan atau jabatan yang menuntut keahlian tertentu.(Susanto,2021:13). 
Sedangkan profesi keguruan adalah jabatan yang memerlukan keahlian khusus sebagia guru dan tidak dapat dilakukan oleh sembarang orang diluar bidang pendidikan. Seorang guru berkaitan dengan aktivitas profesinya diharuskan mengetahui dan dapat menerapkan beberapa prinsip mengajar agar ia dapat melaksanakan tugasnya secara profesional. Guru merupakan profesi tertua didunia seumur dengan keberadaan manusia. Guru merupakan pendidikan profesional dengan tugs uatama mendidik, mengajar, membimbing, mengarahkan, melatih, menilai, dan mengevaluasi peserta didik .

\section{PERAN GURU SEBAGAI SEBUAH PROFESI}

Guru dapat digolongkan sebagai sebuah profesi mengapa demikian karena sebuah profesi merupakan suatu pekerjaan atau jabatan yang menuntut keahlian yang didapatkan melalui pendidikan dan latihan tertentu, dan menurut syarat memiliki kode etika tertentu. Dalam ari profesi ini tidak dapat dilakukan oleh sembarang orang karena pekerjaan yang bersifat profesional berbeda dengan pekerjaan yang lainnya karena profesi ini memerlukan kemampuan dan keahlian khusus dalam melaksananakn profesinya. Dan profesi guru ini merupakan karir seumur hidup dan ada konsekuensinya atas pekerjaan dibidang ini, dan fokus utanya terletak pada pengabdin dan tanggung jawab moril sesuai dengan bidang keilmuan keguruan. Nah dapat kita ketahui dari penjelasan tadi bahwa guru merupakan suatu jabatan yang merupakan keahlian khusus sebagai guru dan tidak dapat dilakukan oleh sembrang orang diluar bidang pendidikan. Meskipun pada kenyataannya masih terdapat guru yang tidak memiliki latar belakang pendidikan dibidang keguruan.

Berdasarkan Undang-Undang No.14 tahun 2005 tentang guru dan dosen, guru adalah pendidikan profesional dengan tugas utama mendidik, mengajar, membimbing, mengarahkan, melatih, menilai dan menevaluasi peserta didik pada pendidikan anak usia

dini jalur pendidikan formal, pendidikan dasar, dan pendidikan menengah. Guru Dan Dosen adalah pendidikan profesional dan ilmu dengan tugas utama mentraformasikan, menggambarkan, dan menyebarluaskan ilmu penetahuan, teknologi, dan seni melalui pendidikan, penelitian dan pengabdian kepada masyarakat.

Djamarah(2000: 42-49) menguraikan banyak peran yang dijalankan guru sebagai pendidik, atau siapa saja yang telah menerjunkan diri menjadi guru. Semua peran diharapkan dari guru seperti berikut;

-Korektor, peran ini mengharuskan guru memahami betul permasalahan dalam proses pendidikan. Sebagai korektor, guru harus bisa membedakan mana nilai yang baik dan mana nilai yang buruk.

-Inspirator, sebagai ispirator guru dapat memberikan ilham yang baik bagi kemajuan belajar peserta didik. Dalam peran ini guru diharuskan untuk menjadi role model bagi peserta didik, guru harus dapat memberikan petunjuk bagaimana cara belajar yang baik. 
-Informan, guru harus dapat memberikan informasi perkembangan ilmu pengetahuan dan tekhnologi, selain sejumlah bahan pelajaran untuk setiap mata pelajaran yang telah diprogramkan dalam kurikulum.

-Organisator, guru merupakan organisator terkait pengelolaan proses pembelajaran, guru memiliki kegiatan pengelolaan kegiatan akademik, menyusun tata tertib kelas/sekolah, menyusun rencana pembelajaran sesuai kalender akademik, dan sebagainya.

-Motivator, guru mampu mendorong peserta didik agar bergairah dan aktif belajar. Dalam upaya memberikan motivasi, guru dapat menganalisis moti-motif yang melatarbelakangi peserta didik malas belajar.

-Inisiator, guru dapat menjadi pencetus ide-ide kemajuan dalam pendidikan dan pengajaran. Isiniator dimaksud mencangkup peran inisiatif guru dalam pembelajaran dalam peran inisiatif guru dalam mengembangkan iklimbelajar di sekolah.

-Fasilitator, guru diharuskan untuk dapat memfasilitasi peserta didik dalam proses belajar mengajar, dalam pengertian dapat mengelola sumber daya yang tersedia sedemikian rupa sehingga memungkinkan siswa dapat memperoleh pengalaman belajar yang sesuai dengan tingkat perkembangan mereka.

-Pembimbing, peran ini harus lebih penting karena kehadiran guru di sekolah adalah untuk membimbing peserta didik menjadi manusia dewasa susila yang cakap.

-Demonstator, tidak semua bahan pelajaran dapat peserta didik pahami. Untuk bahan pelajaran yang sukar dipahami peserta didik, guru harus kreatif untuk menunjukan langsung kepada peserta didik kemampuan yang harus dipelajari.

-Pengelolaan kelas, guru hendaknya dapat mengelola kelas dengan baik, karena kelas adalah tempat berhimpun semua peserta didik dan guru dalam rangka menerima bahan pelajaran dari guru.

-Mediator, guru harus memahami bagaimana siswa berinteraksi dan merespon suatu keadaan.

-Surpervisor, guru harus menunjukan kemampuan untuk menawarkan alternatif solusi atas permasalahan yang ditemukan.

-Evaluator, guru setidaknya diharapkan pada dua proses penting, pertam proses mengukur keberhasilan belajar peserta didik, kedua guru memberikan judgement nilai yang akan menjadi tolah ukur apakah peserta didik berhasil dalam proses belajar atau belum berhasil.

Dalam UU No. 14 Tahun 2005 tentang guru dan dosen mengenai hak dan kewajiban, adapun hak yang dimiliki oleh seorang gurusebagai berikut:

- Memperoleh penghasilan di atas kebutuhan hidup minimum dan jaminan kesejahteraan sosial.

- Mendapat promosi dan penghargaan sesuai dengan tugas dan prestari kerja.

- Memperoleh perlindungan dalam melaksanakan tugas dan hak atas kekayaan intelektual.

- Memperoleh kesepakatan untuk meningkatkan kompetensi. 
- Memperoleh dan memanfaatkan sarana dan prasarana pembelajaran untuk menunjang kelancaran tugas profesional.

- Msmiliki kebebasan dalam memberikan penilaian dan ikut menentukan kelulusan, penghargaan, dan atau sanksi kepada peserta didik sesuai dengan kaidah pendidikan, kode etika guru, dan peraturan perundang-undang.

- Memperoleh rasa aman dan jaminan keselamatan dalam melaksanakan tugas.

- Memiliki kebebasan untuk berserikat dalam organisasi profesi.

- Memiliki kesempatan untuk berperan dalam penentuan kebijakan pendidikan.

- Memperoleh kesempatan untuk mengembangkan dan meningkatkan kualifikasi akademik dan kompetensi.

- Memperoleh pelatihan dan pengembangan profesi dalam bidangnya.

Dalam me;laksanakan tugasnya keprofesionalan dalam UU No. 14 Tahun 2005 tentang gurub dan dosen, guru berkewajiban sebagai berikut:

- Memecahkan pembelajaran, melaksanakan proses pembelajaran yang bermutu, serta menialia dan mengevaluasi hasil pembelajaran.

- Mengembangkan dan meningkatkan kualifikasi akademik dan kompetensi secara berkelanjutan sejalan dengan perkembangan ilmu pengetahuan, tekhnologi dan seni.

- Bertindak objektif dan tidak diskriminsi atas dasar pertimbangan jenis kelamin, agama, suku, ras, dan kondisi fisik tertentu, atau latar belakang, keluarga dan status sosial ekonomi peserta didik dalam pembelajaran.

- Menjunjung tinggi peraturan perundang-undangan, hukum dan kode etika guru, serta nilai-nilai agama dan etika.

- Memelihara dan memupuk persatuan dan kesatuan bangsa.

\section{GURU INDONESIA DAN TANTANGAN PROFESIONALISME}

Profesional sering diartikan sebagai suatu keterampilan teknis yang dimiliki seorang, Misalnya seorang guru dikatan profesional bila guru itu memiliki kualitas pembelajarn yang tinggi, untuk memajukan pendidikan Indonesia tentunya perlu dalam memajukan pendidikan Indonesia, dalam sejarah pendidikan indonesia, guru pernah mempunyai status yang sangat tinggi dalam masyarakat, mempunyai wibawa yang sangat tinggi, dan dianggap sebagi orang yang serba tahu. Peranan guru saat itu tidak hanya mendidik anak didepan kelas, tetapi mendidik masyarakat, tempat bagi masyarakat untuk bertanya, baik untuk memecahkan masalah pribadi atau masalah soail. Dengan perkembangan zaman seperti saat ini seperti era tekhnologi yang maju sekarang guru harus memiliki sikap profesional dan dapat mengikuti perkembangan zaman dan menguasai tekhnologi agar dapat memberikan pembelajaran kepada peserta didik tersampaikan dengan baik. 
Kompetensi profesional merupakan kemampuan dasar yang harus dimiliki oleh guru, Menurut Permendiknas Nomor 16 Tahun 2007 indikator kompetensi profesional seperti berikut:

-mengusai materi, struktur, kosep, dan pola pikir, dan keilmuan yang mendukung mata pelajaran yang dismpu.

- menguasai standar kompetensi dan kompetensin dasar mata pelajaran yang yang diampu

-mengembangkan materi pelajaran yang diampu secara kreatif

-Mengembangkan keprofesionalan secara berkelanjutan dengan melakukan tindakan refleksi

-Memanfaatkan tekhnologi informasi dan komunikasi untuk mengembngkan diri.

Maka kompetendi profesional pada dasarnya merupakan kompetensi keilmuan sesyai dengan bidang tugas guru. Selain dituntut untuk memiliki kompetensi profesional, seorang guru juga harus bisa mengembangkan keprofesinalannya.

\section{SIMPULAN}

Profesi guru merupakan profesi yang sangat penting dan berkontribusi langsung terhadap kemajuan suatu bangsa. Sebagai suatu profesi, guru idealnya memiliki syarat-syarat khusus untuk di jalani oleh seseorang. Diperlukan kompetensi kusus untuk menjadi seorang guru. Guru merupakan posisi yang strategis bagi pemberdayaan dan pembelajaran suatu bangsa yang tidak mungkin digantikan oleh unsur manapun dan kehidupan sebuah bangsa sejak dulu. Profesi guru juga dilengkapi dengan undang-undang yang menjamin hak dan kewajiban guru indonesia. Regulasi dan seperangkat tata nilai tersebut dibuat untuk menjamin profesi guru dapat berperan maksimal dalam proses pendidikan. Seperti layaknya profesi lain, untuk menjadi guru profesional diperlukan berbagai kriteria tersebut berupa landasan keprofesionalan profesi guru dan kompetensi guru sebagaimana temuan dalam undang-undang guru dan dosen serta tentang mentri pendidikan nasional tentang kompetensi guru. Untuk dapat disebut guru profesional tidak hanya diperluakan kualifikasi pendidikan kesejahteraan bidang pendidikan, melainkan juga pemenuhan terhadap kompetensi profesional.

\section{REFERENSI}

Efendi, I., Prawitasari, M., \& Susanto, H. (2021). Implementasi Penilaian Pembelajaran Pada Kurikulum 2013 Mata Pelajaran Sejarah. Prabayaksa: Journal of History Education, 1(1), 21-25.

Susanto, H. (2020). Profesi Keguruan. Banjarmasin: FKIP Universitas Lambung Mangkurat. 
Susanto, H., \& Akmal, H. (2018). Efektivitas Penggunaan Aplikasi Pembelajaran Berbasis Mobile Smartphone Sebagai Media Pengenalan Sejarah Lokal Masa Revolusi Fisik Di Kalimantan Selatan Pada Siswa Sekolah Menengah Atas. HISTORIA: Jurnal Program Studi Pendidikan Sejarah, 6(2), 197-206.

Susanto, H., Irmawati, I., Akmal, H., \& Abbas, E. W. (2021). Media Film Dokumenter Masuknya Islam Ke Nusantara dan Pengaruhnya Terhadap Keterampilan Berpikir Kritis Siswa. HISTORIA: Jurnal Program Studi Pendidikan Sejarah, 9(1).

Syaharuddin, S., \& Susanto, H. (2019). Sejarah Pendidikan Indonesia (Era Pra Kolonialisme Nusantara sampai Reformasi). Banjarmasin: FKIP Universitas Lambung Mangkurat.

Hamalik, Oemar. Pendidikan Guru Berdasarkan Pendekatan Kompetensi. Cet. V; Jakarta: Bumi Aksara, 2008.

Soetjipto., \& Kosasi , Raflis. (2011). Profesi Keguruan. Jakarta Kompleks Perkantoran Mitra Matraman. 